\title{
THE TRANSFORMATIONAL PARADIGM OF THE PESANTREN CURRICULUM INNOVATION
}

\author{
Fata Asyrofi Yahya \\ State Institute of Islamic Studies (IAIN) Ponorogo \\ Email: asyrofi@iainponorogo.ac.id
}

\begin{abstract}
This research begins from the problems faced in pesantren. They include curriculum management and learning, such as the implementation of teacher-centered learning and poorly planned learning evaluation. Thus, the researcher is interested in studying Pesantren Nurul Iman Garum Blitar, which applies an innovative curriculum using a transformative paradigm. The research method was qualitative research - a phenomenological approach. The findings were; first, there were three curriculum objectives: national goals, institutional goals, and learning objectives. Second, the learning material was reconstructing several books in the pesantren, such as the nahwu, shorof, and fiqh books. Third, the learning method was student-centred which encourage students to be active. In addition, it was also supported by some learning programs, including takror sughro, takror kubro, and syawir. Fourth, the learning evaluation employed formative and summative evaluation.
\end{abstract}

Abstrak: Penelitian ini berawal dari kegelisahan akademik peneliti melihat beberapa problematika yang terjadi di pondok pesantren, diantaranya problem pengelolaan kurikulum dan pembelajaran, seperti metode pembelajaran yang cenderung teacher centered dan juga evaluasi pembelajaran yang tidak terencana dengan baik. Dari situ peneliti tertarik meneliti Pondok Pesantren Nurul Iman Garum Blitar yang membuat inovasi dalam kurikulumnya dengan menggunakan paradigma transformatif. Metode penelitian ini menggunakan pendekatan fenomenologis dan jenis penelitian kualitatif. Diantara hasil penelitiannya sebagai berikut: pertama, desain tujuan kurikulumnya terdiri dari tiga macam; yaitu tujuan nasional, tujuan institusional dan tujuan pembelajaran. Kedua, desain materi pembelajarannya berupa rekonstruksi ulang beberapa kitab di pesantren, seperti kitab nahwu, shorof dan fikih. Ketiga, desain metode pembelajarannya menggunakan paradigma student centered dengan metode yang mendorong siswa aktif. Selain itu didukung dengan beberapa program pembelajaran, diantaranya takror sughro, takror kubro dan syawir. Keempat, bentuk evaluasi pembelajarannya menggunakan evaluasi formatif dan sumatif.

Keywords: innovation; curriculum; pesantren 


\section{INTRODUCTION}

Pesantren is an indigenous institution that has a significant contribution to the establishment and sustainability of the Indonesian nation. The character of pesantren is in line with the Indonesian national ideology. According to Dr. Sutomo, as written by Ahmad Baso, these characters include: first, knowledge to their students. Second, provide the tools to fight in this world. Third, education with a national spirit, love for the homeland and nation, and the world and fellow human beings in general. Fourth, students will make themselves available to support public needs. Fifth, inner strength is educated. Spiritual intelligence is taken seriously. So, the knowledge received by him can be used and provided to serve public needs. ${ }^{1}$

Besides the ideal education values of pesantren, there are still many problems faced in its practice, mainly in Salaf pesantren, whose management is still conservative. As Mudjamil criticizes several aspects of the weaknesses of the multidimensional pesantren: first, the weakness in terms of management, where most of the traditional pesantren are still mono-management and monoadministrative, there is no division of authority to units within the organization. Second, the position and power of the kiai. The direction and purpose of the pesantren are kiai-centered. He is the decision-maker. Third, the teachinglearning used in pesantren is teacher-centered. in terms of learning. ${ }^{2}$

Based on the reality on the curriculu $\mathrm{m}$ of pesantren, the program that urgently needs to be improved is its innovation. Of course, Pesantren should maintain the ideal existing curriculum values. But, on the other hand, it needs a transformation to develop the pesantren. Thus, it needs a transformative curriculum innovation. It means that it changes and develops the form and characteristics and maintains the value of the existing pesantren value.

One of the pesantren that are currently innovating their curriculum is Pesantren Nurul Iman Islamic Garum Blitar. Based on initial observations, the authors obtained information from several informants directly involved in the curriculum innovation, including Kiai Syamsul.

"Memang benar mas di pondok pesantre n Nurul Iman ini, senantiasa dilakukan perubahan-perubahan terutama dalam aspek kurikulumnya sehingga bisa memenuhi kebutuhan santri saat ini. Mereka membutuhkan bentuk kurikulum yang memudahkan mereka untuk memahami secara mudah dan mendalam tanpa harus merubah nilai-nilai yang sudah terpola di pesantren, mulai dari materinya, motode, evaluasi dan juga media yang dipakai. Misalnya

1 Ahmad Baso, Pesantren Studies 2a, Buku II: Kosmopolitanisme Peradaban Kaum Santri Di Masa Kolonial, Juz Pertama: Pesantren, Jaringan Pengetahuan Dan Karakter KosmopolitanKebangsaannya (Jakarta: Pustaka Afid, 2015), 24.

2 Mujamil Qomar, Manajemen Pendidikan Islam: Strategi Baru Pengelolaan Lembaga Pendidikan Islam (Erlangga, 2007), 58. 
saja kami membuat modul baru dalam beberapa mata pelajaran yang dipakai di pesantren seperti dalam bidang aqidah, fikih, ilmu alat dan akhlak, dan itu terus kami kembangkan ke arah yang lebih luas cakupannya." ${ }^{3}$

From the information gathered, this research focuses on developing the pesantren curriculum at Pesantren Nurul Iman Garum Blitar. This study consists of four research problems. First, how to design a transformative paradigm of curriculum objectives; second, how to design learning materials with a transformative paradigm; third, how to design a transformative paradigm of learning methods; fourth, how to design a transformative paradigm of learning evaluation. Hence, this study aims to formulate (1) the objectives, (2) learning materials, (3) learning method, and (4) evaluation of transformative paradigm learning.

\section{RESEARCH METHOD}

This research employed qualitative research. It used a phenomenology approach to investigate a particular situation that supports the quality of a program the transformational paradigm of curriculum innovation at Pesantren Nurul Iman Garum Blitar. This study used an interactive model of analysis adapted from Miles \& Huberman. It consisted of data reduction (choosing the suitable data), data collection, data display, and conclusion. ${ }^{4}$ The data analysis aimed to process and construct the research findings. The data were collected through observation, interviews, and documentation. It displayed systematically, so others could comprehensive it well.

\section{THEORETICAL FRAMEWORK}

\section{The Basic Concept of Transformative Paradigm of Pesantren Curriculum Innovation}

The word "innovation" is taken from the English language, namely innovation. In the Indonesian dictionary, the word innovation means a new invention that is different from existing or previously known ones (ideas, methods, or tools). ${ }^{5}$ Innovation is also often interpreted as "modernization, " linking the word because there is an effort to renew innovation. Innovations are carried out aiming to solve a particular problem. For example, in educational innovation, school-based management (SBM) is applied to improve managerial aspects

3 Interview with kiai Syamsul Hadi, the chief of the Curriculum Development of Pesantren Nurul Iman Garum Blitar dan Imam Muhtakim, as the users of Madin curriculum Madin Nurul Iman in Pesantren Hudatul Muna 2 Jenes Ponorogo at 2 Juli 2019.

${ }^{4}$ Matthew B. Miles and A. Michael Huberman, Analisis Data Kualitatif. Terjemahan Tjetjep Rohendi Rohidi (Jakarta: UI Press, 1992), 16.

5 Ebta Setiawan, "Kamus Besar Bahasa Indonesia Versi Online," Dalam KBBI. Web. Id/ Kadas-2, Diakses Tanggal 1 agustus 2019. 
in educational institutions, and innovations in life skills-based curriculum to contextualize education in schools with the needs of students in employment. ${ }^{6}$

The practice of innovation is often carried out in education in various aspects, such as personnel management, infrastructure, and curriculum. In this study, the authors focus on innovation in the curriculum aspect. The language "curriculum" is taken from Greek, namely curir or curere, which means the distance that a runner must travel. ${ }^{7}$ Meanwhile, according to experts, it has several scopes of understanding when the curriculum is associated with education. First, the curriculum is defined as subject matter. Second, the curriculum is defined as a learning experience, and third, the curriculum as a learning program planning. ${ }^{8}$

From the description above, curriculum innovation can be interpreted to find something new in curriculum management regarding subject matter, learning experiences, and planning learning programs based on finding solutions to specific problems.

In the practice of curriculum innovation, systematic and measurable steps are needed. Therefore, curriculum innovation requires tools that can be taken from the following curriculum development theories. ${ }^{9}$

1. Curriculum Development Approach

In the curriculum development process, one of the following approaches can be used: Field of Study Approach, Interdisciplinary Approach, Reconstructionist Approach, Humanistic Approach, National Development Approach, and Technological Approach.

2. Curriculum Development Steps

In curriculum development, systematic steps are needed to make it easier to make the required design. Among the steps that can be taken are as follows: conducting a need assessment, determining subjects, formulating learning objectives, determining student learning outcomes for each subject, determining the topics discussed in each subject, determining the requirements for the requirements required of students, determine reading references for students, determine learning strategies and media, determine the students learning outcomes, evaluation tools, and assessment scales, design a comprehensive curriculum assessment and at the same time its improvements. ${ }^{10}$

${ }^{6}$ M. Sulthon Masyhud dan Khusnuridho, Manajemen Pondok Pesantren (Departemen Agama, 2003), 64.

7 S. Nasution, Asas-Asas Kurikulum (Jakarta: Bumi Aksara, 1995), 3.

8 Nana Syaodih Sukmadinata, Pengembangan Kurikulum Teori Dan Praktek (Bandung: Remaja Rosda Karya, 2009), 4.

9 Masyhud, Manajemen Pondok Pesantren, 75.

${ }^{10}$ Masyhud, 79. 
The term "pesantren" is taken from the word "santri," which means people who have a desire to study religion, as opposed to the Javanese tradition called the "abangan." Based on some experts, the term "santri" comes from the word "sastri" and also "cantrik." Suppose santri comes from the word "sastri" which means literate people. In that case, this meaning is used because a santri has a habit of understanding religious sciences from Arabic books. Their habit is a reading culture. Meanwhile, if "santri" is taken from the word "cantrik," it means people who always follow their teachers wherever they are. So that this second meaning makes pesantren often associated with the term "pondok," which means the place where students live in studying; these two terms are often referred to as pesantren. ${ }^{11}$

Pesantren has distinctive components that distinguish it from other forms of educational institutions. Some components in pesantren are pondok/ dormitories, mosques, kitab kuning, and kiai. ${ }^{12}$ From its uniqueness, it makes pesantren an original Indonesian educational institution (indigenous). In its development, this pesantren experienced various typologies. Typologically, there are some types of pesantren. They are traditional pesantren (salaf), khalaf and the mixed. ${ }^{13}$ The various typologies mentioned above show that Pesantren always moves dynamically to show its existence as an educational institution in Indonesia.

While the word "paradigm" is etymologically taken from the Greek "para." It means next to or beside, and the word "diegma" means exemplary, ideal, model, or archetype. ${ }^{14}$ This word also comes from English "paradigm," which means the type of something, model, pattern (the form of something, model, pattern). ${ }^{15}$ Thus, the terminology "paradigm" is a way of thinking or looking at something. ${ }^{16}$ Furthermore, the word "transformative" is taken from the English word transformation, which means a change of appearance in form, nature, and function. ${ }^{17}$ The meaning is the same when "transformation" is taken from the Latin transformatio. ${ }^{18}$ The word "transformation" also has the same meaning

${ }^{11}$ Nurcholis Madjid, Karya Lengkap Nurcholis Madjid: Keislaman, Keindonesiaan Dan Kemodernan (Jakarta: Nurcholish Madjid Society, 2019), 3267.

${ }^{12}$ Zamakhsyari Dhofier, Tradisi Pesantren: Studi Tentang Pandangan Hidup Kyai (Lembaga Penelitian, Pendidikan, dan Penerangan Ekonomi dan Sosial, 1982), 79.

${ }^{13}$ Mudjamil Qomar, Pesantren: dari Transformasi Metodologi Menuju Demokratisasi Institusi (Erlangga, 2002), 16,

${ }^{14}$ Lorens Bagus, Kamus Filsafat (Gramedia Pustaka Utama, 2000), 779.

${ }^{15}$ Ismail SM, ed, Paradigma Pendidikan Islam (Semarang: Pustaka Pelajar, 2001), viii.

${ }^{16}$ Ismail SM, ed, 8.

${ }^{17}$ Peter Salim, Adventage: Inggris-Indonesia Dictionory (Jakarta: Moderen English Press, 1988), 902.

${ }^{18}$ Osman Raliby, Kamus Internasional (Jakarta: Bulan Bintang, 2000), 536. 
as the words tajdid, reformation, and modernization, which means renewal. ${ }^{19}$ According to the writer's opinion, the meaning of transformation is a change that retains its original characteristics.

From those definitions, it can be concluded that the purpose of the transformational paradigm of pesantren curriculum innovation is to update in developing the pesantren curriculum. So it is by changing the characteristics, form, and function but still maintaining the characteristics of the pesantren.

\section{Components of Transformative Paradigm of Pesantren Curriculum Innovation}

Curriculum innovation should consider the components of curriculum development. It can be derived from Tyler Rationale in his theory of curriculum development. According to Tyler, as quoted by Tanner, innovation and curriculum development departs from four basic questions: first, what is the goal to be achieved? Second, what kind of teaching materials can lead to these goals? Third, what teaching and learning strategies are effective in achieving these goals? Fourth, what kind of evaluation is suitable with the objectives to be achieved? ${ }^{20}$

From some of these questions, the curriculum components can be formulated into four things, namely:

\section{Components of Curriculum Objectives}

The objectives to achieve student competence in the curriculum formulation are the essential things underlie the other components' formulation. The determination of these goals is based on the community's needs and the philosophical foundations that overshadow them. Thus, education goals have a clear direction. ${ }^{21}$

According to Kennet T. Hanson in his book "The Curriculum Development for Education Reform," the words aim, goals and objectives. Various curriculum objectives include; first, aim, is the goal of national education, as stated in the preamble of the 1945 Constitution in the fourth paragraph of the goal of national education, namely the nation's intellectual life. Second, goals are defined as institutional or institutional goals, for example, forming students with noble character and mastering science and technology. Third, objectives are defined as learning objectives. They are adjusted to competency standards (SK) and Basic Competencies (KD) as measured by indicators of learning success achievement. ${ }^{22}$

${ }^{19}$ A Malik M. Thaha ed, Modernitas Pesantren (Jakarta: Puslitbang Depag RI, 2007), 8.

${ }^{20}$ Daniel Tanner and Laurel N. Tanner, Curriculum Development: Theory into Practice (Prentice Hall, 1995), 84.

${ }^{21}$ Syaodih Sukmadinata, Pengembangan Kurikulum Teori Dan Praktek, 103.

${ }^{22}$ Ibid, 12. 


\section{Components of Learning Materials}

Among the material components that are made, at least meet three aspects of student competence as the object of its development, namely affective, cognitive and psychomotor aspects. The presentation of material that refers to the three competencies requires a balance, especially quantity. Students' abilities between the three aspects of their development can be balanced to form humanists, intellectuals, and creative. ${ }^{23}$

The subject matter in Pesantren has its characteristics called kitab kuning. Among the types of knowledge can be classified into eight groups, including 1) nahwu (syntax) and shorof (morphology); 2) fiqh; 3) ushul fiqh; 4) hadith; 5) interpretation; 6) monotheism; 7) Sufism and ethics; 8) other branches such as tarikh and balaghah. ${ }^{24}$

\section{Components of Learning Method}

The formulation of teaching and learning methods considers the presentation of the delivered material. It is the material that contains affective, cognitive, and psychomotor aspects. The three contents of the material that cover the three competencies above require different strategies to be used. Still, using strategies emphasized in using the constructivism educational psychology paradigm to refer to student-centered learning is no longer teacher-centered. From this learning model, the task of an educator is as a motivator, facilitator, and guide. ${ }^{25}$

Some examples of learning methods in Islamic education are as follows. First, the lecture method. The second, the demonstration method. The third method tutorial/guidance. Fourth, the method of discussion. Fifth, the tajribat (experimental) method. Sixth assignment. Sixth, the drill method (practice). Seventh, the question and answer method. Eighth, simulation method. Ninth, the method of proverbs and tenth methods of understanding and reasoning. ${ }^{26}$ In addition to the examples above, there are many other learning methods formulated by education experts.

4. Learning Evaluation Components

According to Arifin, as quoted by Asrul et al., learning evaluation is a systematic and continuous process to determine the quality (value and meaning) of something. It is based on specific considerations and criteria to make a decision. ${ }^{27}$

In designing this evaluation, of course, it is also adjusted to the content of the existing material, both referring to affective, cognitive, and psychomotor

${ }^{23}$ Adeng Chaedar Alwasilah, Filsafat Bahasa Dan Pendidikan (Diterbitkan atas kerjasama Sekolah Pasca Sarjana Universitas Pendidikan ..., 2008), 106.

${ }^{24}$ Dhofier, Tradisi Pesantren., 87.

${ }^{25}$ Adeng Chaedar Alwasilah, Filsafat Bahasa dan Pendidikan, 106.

${ }^{26}$ Ibid., 20.

${ }^{27}$ Asrul, Rusydi Ananda, and Rosnita Rosnita, Evaluasi Pembelajaran (Citapustaka Media, 2015), 4 . 
aspects. It requires variations in different assessment forms among the three component aspects, as stated in the government regulation on assessment standards. The affective aspect is assessed through observation, peer assessment, personal assessment, and journals. The cognitive aspect uses test, non-test, and assignment forms of assessment. In contrast, the psychomotor aspect uses the form of practical, project, and portfolio assessments. ${ }^{28}$

The four components of the curriculum in their preparation must be interrelated so that one component is in line with the scope of the other components. It can be achieved when the preparation is carried out systemically. Thus, all curriculum formulators understand the flow of curriculum implementation, starting from planning, implementation, and evaluation.

\section{RESEARCH FINDINGS AND DISCUSSION \\ The Design of Transformative Paradigm Curriculum Goals}

In formulating the objectives of the curriculum must be designed clearly. One thing that needs to be considered, especially for Pesantren, is the contextualization and relevance of the pesantren curriculum to the times. Therefore, curriculum innovation in Pesantren as the most prominent Islamic educational institution in Indonesia is vital so that pesantren can still exist. It is in line with Nur Efendi's view in his book Manajemen Perubahan di Pondok Pesantren. He said that if Islamic educational institutions respond to the rhythm of change through intelligent and creative innovations, their opportunity to survive will be tremendous. However, suppose Islamic educational institutions are unable or slow to respond to dynamics changes, sooner or later. In that case, Islamic educational institutions will be left behind and automatically abandoned by the community. ${ }^{29}$

Pesantren Nurul Iman Garum Blitar is one of the pesantren that is responsive to change. One of the changes made is the innovation of the madrasah diniyah curriculum. This innovation was created starting from the anxiety of $\mathrm{KH}$. As the caretaker of Pesantren Nurul Iman, Saiful Bahri saw the low quality of pesantren graduates with a relatively long education period. He sees the need for curriculum reconstruction in pesantren so that the quality of learning and graduates can be optimal. $\mathrm{KH}$ raises the idea. In targeting the curriculum aspect as the object of innovation, Saiful Bahri is in line with the views of Sulthan Masyhud and

${ }^{28}$ Departemen Pendidikan dan Kebudayaan, Permendikbud No. 23 Tahun 2016 Tentang Standar Penilaian Pendidikan (Jakarta: Permendikbud, 2016).

${ }^{29}$ Nur Efendi, Manajemen Perubahan di Pondok Pesantren (Yogyakarta: Kalimedia, 2014), 9. 
Khusnurridho. They stated that educational innovation is needed, including curriculum subject matter, learning methods, various supporting facilities. ${ }^{30}$

Pesantren Nurul Iman as a form of traditional pesantren, uses kitab kuning curriculum as its teaching guide. The material in the form of kitab kuning cannot be separated from the material carried in pesantren. Five main elements must be in pesantren. Zamahsyari Dhofier emphasizes $i^{31}$. They are the mosque, pondok, kitab kuning, santri, and kyai. In addition, the value in the form of the ideology of ahlussunah wal jama'ah contained in kitab kuning is the primary teaching carried by the pesantren. Hence, it seems to be a package between kitab kuning and the ideology of ahlussunah wal jama'ah in it. ${ }^{32}$

The process of curriculum innovation at Pesantren Nurul Iman does not change and eliminate the fundamental values mentioned. However, its changes are only made in the packaging to formulate learning objectives, books, or learning guide books, methods, and evaluations. The innovation uses the transformative paradigm, meaning that the change is only in the packaging without changing its substance. This is in line with the opinion of Suradi and Mukhlison in their work entitled Transformasi Kurikulum Pesantren: Telaah Pemikiran KH. MA. Sahal Mahfudz dan Nurcholis Madjid stated the meaning of the transformation of the pesantren curriculum as a change in the form, nature, and function of the pesantren curriculum without losing the characteristics and identity of the pesantren itself. ${ }^{33}$

While the author's analysis related to curriculum goals designed in curriculum innovation at the Pesantren Nurul Iman concludes three formulations of goals: national, institutional, and learning goals. The national goals that have been made are clearly in line with the mandate of the 1945 Constitution to educate the nation's life. In comparison, the institution's goal to be achieved is to form students who completely master kitab kuning easily and quickly. The specific objectives or learning objectives are that students can memorize, understand and analyze each subject matter correctly and adequately. From findings, it can be seen that the form of the designed curriculum objectives is in accordance with the opinion of Kennet T. Hanson in his book The Curriculum Development for Education Reform which said that there are three goals in the curriculum:

${ }^{30}$ M. Sulthon Masyhud, Manajemen Pondok Pesantren (Jakarta: Departemen Agama, 2003), 64 .

${ }^{31}$ Zamakhsyari Dhofier, Tradisi Pesantren: Studi Tentang Pandangan Hidup Kyai (Lembaga Penelitian, Pendidikan, dan Penerangan Ekonomi dan Sosial, 1982), 79.

${ }^{32}$ Ibid., 228.

${ }^{33}$ Mukhlison Effendi and Suradi Suradi, "Transformasi Kurikulum Pesantren: Telaah Pemikiran KH. MA. Sahal Mahfudh Dan Nurcholish Madjid,” Cendekia: Jurnal Kependidikan Dan Kemasyarakatan 12, no. 1 (2014): 15-32. 
national, institutional, and learning. ${ }^{34}$ From the three formulations of objectives, it can be understood how the design of curriculum innovation goals at Pesantren Nurul Iman Garum Blitar uses a transformative paradigm.

\section{Transformative Paradigm Learning Material Design}

The subject matter prepared as lesson material must be prepared and arranged and have positive implications for learning outcomes. The form of the subject matter used in Pesantren Nurul Iman is in textbooks in the form of books. As explained by Assep Hery et al., textbook teaching materials are books used in the learning process. It contains teaching materials that are systematically arranged from a subject or study material that at least must be mastered by students at a certain level and type of education. ${ }^{35}$

Among the objects of curriculum innovation carried out at Pesantren Nurul Iman is the material component in textbooks. As an institution in the form of a pesantren, the widely used textbooks are in the form of kitab kuning. Among the subjects that are the subject of discussion are the subjects of nahwu, shorof, fiqh, monotheism, and morals. Of the five scientific subjects, the teaching materials used as objects of innovation and reconstruction are nahwu, shorof, and fiqh subjects. As for the subjects of monotheism and morality, they still use textbooks in the form of books written by previous scholars, only differ in the method and evaluation of learning. Among the nahwu books that were written and reconstructed were the lay books of al-jurjani, Jurumiyah, 'imrithi, and alfiyah. While the science of shorof, which usually consists of three subjects, namely amtsilah al-tasrifiyyah, qawa'id al-asharfiyyah, and qawa'id al-i'lal, was rewritten and reconstructed into the book treatise al-shorfiyyah volumes 1,2 , and 3 . The reconstructed fiqh book is the fiqh al-mubtadi book. Suppose you look at the innovation model carried out. In that case, the type of approach used in the field of study approach (discipline), namely the science of religion. It is as explained by Masyhud and Khusnurridho in their book Management of Pesantren. The innovation and curriculum development with a field of study approach makes subjects the basis for curriculum organization, for example, groups in general studies, groups in religious studies, and others. ${ }^{36}$ From the innovation model in teaching materials, it can be seen that the transformative paradigm is that kitab kuning is used as the teaching material. It is the main component that cannot

${ }^{34}$ Agus Zaenul Fitri, Manajemen Kurikulum Pendidikan Islam, Dari Normative-Filosofis Ke Praktis (Bandung: Alfabeta, 2015), 12.

${ }^{35}$ Asep Herry Hernawan, Hj Permasih, and Laksmi Dewi, "Pengembangan Bahan Ajar," Direktorat UPI, Bandung, 2012.

${ }^{36}$ Masyhud, Manajemen Pondok Pesantren. 
be separated from the pesantren. Still, innovation and reconstruction are carried out only in the packaging to make it easier to understand.

Furthermore, in the preparation of teaching materials, systematic steps are needed to be well organized. According to Hamid et al. are, the first is analysis. At this stage, what is needed is to collect information related to the subjects to be developed along with the syllabus. The second is design. It means that what is done is to formulate learning objectives, make test items, determine strategies and media. Third, the writing and preparation of the material. Fourth, evaluation, and fifth, revision. ${ }^{37}$ From the description of the theory, the author sees that the series of material preparation carried out by Team 9 at Pesantren Nurul Iman is in line with the above. Among the steps taken are as follows: determining the subject matter, creating an innovative concept of the subject matter, determining one of the nine teams to rewrite and design the material as a whole, making joint corrections to the composition of the material to revision, and finally publishing.

In addition to the systematic stages described above, three principles are used as parameters in preparing teaching materials. Hence, the composition of the material is effective to be delivered. Among the principles used in the preparation of textbooks at Pesantren Nurul Imaninclude: using the easiest and simplest language possible, using language that is easy to understand, and the arrangement of explanations using the eyes of the student's abilities, not the teacher's will. These principles are permanently adhered to by the textbook compilers who are members of the nine-team. It is in line with the psychological, linguistic, and educational principles described by al-Ghali and Abdullah in the preparation of Arabic textbooks. Adhering to psychological principles means adjusting to students' intellectuals, paying attention to students' individual differences, stimulating students' thinking power, paying attention to students' age level. Thus, the material can stimulate and motivate students to use Arabic. At the same time, the linguistic principle means that the language that is compiled includes the elements and skills of the language so that the material is prepared based on the objectives set. The principle of education means that it is in accordance with educational theory in compiling teaching materials, such as material starting from the easy to the complex and from the concrete to the abstract. ${ }^{38}$

${ }^{37}$ M. Abdul Hamid, Pembelajaran Bahasa Arab: Pendekatan, Metode, Strategi, Materi, Dan Media (UIN-Maliki Press, 2008).

${ }^{38}$ Nashir Abdullah Al Ghali dan Abdul Hamid Abdullah, Usus I'dad Al Kutub Al Ta'liimiyyat Li Ghairi Al Naathiqiin Bihaa (Riyadh: Dar Al Gha, 1991), 19. 


\section{Transformative Paradigm Learning Method Design}

One of the innovations in teaching methods in Pesantren that he initiated is the active learning method using the student-centered learning paradigm. It is in line with Hisham Zaini's view, as quoted by Anip Dwi. One of the factors that cause the information to be quickly forgotten is the weakness of the human brain itself. Therefore, learning that only relies on the sense of hearing has many weaknesses, even though learning outcomes must be stored for a long time. ${ }^{39}$ For this reason, it is crucial to change learning method innovations in Pesantren to become student-centered so that the results can be optimal.

Among the standardized teaching methods in learning books at Pesantren Nurul Iman, the steps are as follows.

1. The teacher reads the subject matter repeatedly

2. Pupils read together under the guidance of the teacher

3. In groups or individually, students read alternately and are listened to together by the teacher and other students until all of them are able to read correctly

4. Students memorize subject matter by means, among others: repeatedly reading, forming groups that are guided by each group leader and the teacher observing

5. The teacher explains the subject matter until all students are able to understand it

6. The teacher evaluates the material by giving random questions to each student

The steps of the teaching method explained are always written on the first page of the textbook; in learning nahwu, shorof and fiqh. So, teachers and students are required to apply the learning design together. The steps mentioned require students to study actively. The author observed how the condition of the atmosphere in the classroom during the lesson, both during madrasah diniyah learning hours, takror sugra, and takror kubra. All students looked active, enthusiastic, and attentive.

Among the six learning steps mentioned, it can be analyzed that there are several active learning methods used in it. They are the drill method, reading load, and the study group. The drilling method is used to train students' activeness and agility in learning. Saiful Sagala explained that the drill method is a training method or training method, which is a good way of teaching to instill certain habits. Also, as a means to acquire agility, accuracy, opportunity, and skill..$^{40}$ The reading load method is how students want to be active in speaking by reading aloud and repeatedly. In comparison, teachers can use the study group method

${ }^{39}$ Anip Dwi Saputro, "Pembelajaran Aktif Dalam Dunia Pesantren," in Seminar Nasional Pendidikan 2015, 2019, 70-79.

${ }^{40}$ Sagala Syaiful, Konsep Dan Makna Pembelajaran Untuk Membantu Memecahkan Problematika Belajar Dan Mengajar (Bandung: Alfabeta, 2013), 21. 
to make students able to communicate actively with their friends in working together in groups. ${ }^{41}$

The teaching method with the six steps above is used for learning nahwu, shorof, and fiqh. As for learning monotheism and morality, the teacher does not use the steps above. In this case, the teacher reads the book with the Arabic pegon reading method. However, in the middle or at the end of the lesson, the teacher gives assignments to the students. He asks them to use words as a medium for practicing or practicing analysis of nahwu and shorof learning. Herein lies the learning innovation that is different from the book's teaching in other places. In this case, students are required to be active in analyzing words to use their knowledge to analyze a particular problem in language. It is in line with the explanation of Chai et al., as quoted by Suwardi Wekke that the learning given to students is not enough to memorize. However, to better understand and increase students' knowledge, they need to be given a particular problem to solve. ${ }^{42}$ In this way, students' knowledge not only stops in their minds but can also be practiced for particular problems and can be remembered for a long time.

In addition to using active student learning methods, another innovation designed at Pesantren Nurul Iman is implementing various other learning programs to form a competitive and integrated learning environment. Other than learning in the madrasah diniyah class, the learning programs are the takror sughro, takror kubro, and syawir programs. The three programs aim to support the acceleration of student achievement in learning in madrasah diniyah class.

With the various programs above, it can form a competitive and integrated learning environment. It can support the acceleration of students in learning Arabic in the form of the kitab kuning. A conducive learning environment, especially in language learning, is needed by students. In line with Halimi's view, the environment has an enormous influence on learning Arabic. The environment is defined as all elements and factors, both material and nonmaterial. It influences the learning process and becomes a stimulant for students to be more enthusiastic in improving language understanding and skills. ${ }^{43}$

\section{Transformative Paradigm Learning Evaluation Design}

Implementation of evaluation in the curriculum also greatly determines the achievement of student learning outcomes. Without a good evaluation, teachers

${ }^{41}$ Mel Silberman, Active Learning: 101 Strategies To Teach Any Subject. (ERIC, 1996).

${ }^{42}$ Muhammad Yusuf and Ismail Suardi Wekke, "Active Learning on Teaching Arabic for Special Purpose in Indonesian Pesantren,” Procedia-Social and Behavioral Sciences 191 (2015): 137-141.

${ }^{43}$ Halimy Zuhdy, "Lingkungan Bahasa Arab Dan Perannya Dalam Belajar Dan Pembelajaran Di Pondok Pesantren Al-Amien Prenduan Sumenep Madura," Uin Maulana Malik Ibrahim Malang, 2007. 
will not know how to provide remedial or enrichment to their students. Among the forms of evaluation of learning at Pesantren Nurul Iman carried out are formative evaluations given at the end of each meeting in oral learning and summative evaluations given at the end of each semester in the form of written and oral tests. These two evaluations are essential to carry out because, as Sujono argues, the purpose of the two evaluations above is to determine the value that symbolizes students' success after receiving lessons within a certain period. ${ }^{44}$

Among the forms of innovation according to the new author and only carried out at Pesantren Nurul Iman is an evaluation in the form of pronouncing words in all learning includes five types of subjects, namely nahwu, shorof, fiqh, monotheism, and morality. The explanations given by the students to i'rob must be in line with the definitions they have learned from the start. So, for example, when students in the Madin Wustho class explain the Arabic word i'rab, it must be based on their information when studying in the Madin Ula class. Therein lies the advantage of evaluation in this curriculum. There is an integration of materials, methods, and evaluations from the beginning of student learning in the Madin Ula class until they graduate from the current third class of Madin Wustho.

\section{CONCLUSION}

Based on the data and explanation related to the transformational paradigm of the pesantren curriculum innovation in Pesantren Nurul Iman Garum Blitar, it can be concluded: first, there are three goals of curriculum: national, institutional, and learning goals. Second, the learning materials reconstruct some books in pesantren, such as nahwu, shorof, and fiqh books. Third, the learning method is student-centered. It stimulates students to be active. Besides, there are some supporting programs, such as takror sughro, takror kubro dan syawir. Fourth, it applies formative and summative evaluation. The formative test is given for takror sughro dan takror kubro. However, the follow-up of summative evaluation is the class grouping based on the students' abilities and providing the enrichment outside of the madrasah diniyah class hours.

${ }^{44}$ Anas Sudijono, Pengantar Evaluasi Pendidikan (PT RajaGrafindo, 1998)., 23. 


\section{REFERENCES}

A Malik M. Thaha ed. Modernitas Pesantren. Jakarta: Puslitbang Depag RI, 2007.

Ahmad Baso. Pesantren Studies 2a, Buku II: Kosmopolitanisme Peradaban Kaum Santri Di Masa Kolonial, Juz Pertama: Pesantren, Jaringan Pengetahuan Dan Karakter Kosmopolitan-Kebangsaannya. Jakarta: Pustaka Afid, 2015.

Alwasilah, Adeng Chaedar. Filsafat Bahasa Dan Pendidikan. Diterbitkan atas kerjasama Sekolah Pasca Sarjana Universitas Pendidikan ..., 2008.

Arikunto, Suharsimi. Prosedur Penelitian: Suatu Pendekatan Praktik. Rineka Cipta, 1992.

Asrul, Asrul, Rusydi Ananda, and Rosnita Rosnita. Evaluasi Pembelajaran. Citapustaka Media, 2015.

Bagus, Lorens. Kamus Filsafat. Gramedia Pustaka Utama, 2000.

Damanhuri, Ahmad, Endin Mujahidin, and Didin Hafidhuddin. "Inovasi Pengelolaan Pesantren Dalam Menghadapi Persaingan Di Era Globalisasi." Ta'dibuna: Jurnal Pendidikan Islam 2, no. 1 (2013): 17-37.

Dhofier, Zamakhsyari. Tradisi Pesantren: Studi Tentang Pandangan Hidup Kyai. Lembaga Penelitian, Pendidikan, dan Penerangan Ekonomi dan Sosial, 1982.

Efendi, Nur. Manajemen Perubahan Di Pondok Pesantren. Yogyakarta: Kalimedia, 2014.

Effendi, Mukhlison, and Suradi Suradi. "Transformasi Kurikulum Pesantren: Telaah Pemikiran KH. MA. Sahal Mahfudh Dan Nurcholish Madjid." Cendekia: Jurnal Kependidikan Dan Kemasyarakatan 12, no. 1 (2014): $15-32$.

Halil, Hermanto, and STAI Miftahul UlumPamekasan. "Inovasi Kurikulum Pesantren Dalam Memproyeksikan Model Pendidikan Alternatif Masa Depan," n.d.

Hamid, M. Abdul. Pembelajaran Bahasa Arab: Pendekatan, Metode, Strategi, Materi, Dan Media. UIN-Maliki Press, 2008. 
124 Fata Asyrofi Yahya, The Transformational Paradigm

Hernawan, Asep Herry, Hj Permasih, and Laksmi Dewi. "Pengembangan Bahan Ajar.” Direktorat UPI, Bandung, 2012.

Ismail SM, ed. Paradigma Pendidikan Islam. Semarang: Pustaka Pelajar, 2001.

Jean Francois Lyotard. Phenomenology. New York: State University of New York Press, 1991.

Kebudayaan, Departemen Pendidikan dan. Permendikbud No. 23 Tahun 2016 Tentang Standar Penilaian Pendidikan. Jakarta: Permendikbud, 2016.

Masyhud, M. Sulthon. Manajemen Pondok Pesantren. Departemen Agama, 2003.

Miles, Matthew B., and A. Michael Huberman. Analisis Data Kualitatif. Terjemahan Tjetjep Rohendi Rohidi. Jakarta: UI Press, 1992.

Nashir Abdullah Al Ghali dan Abdul Hamid Abdullah. Usus I'dad Al Kutub Al Ta'liimiyyat Li Ghairi Al Naathiqiin Bihaa. Riyadh: Dar Al Gha, 1991.

Nasution, S. Asas-Asas Kurikulum. Jakarta: Bumi Aksara, 1995.

Nurcholis Madjid. Karya Lengkap Nurcholis Madjid: Keislaman, Keindonesiaan Dan Kemodernan. Jakarta: Nurcholish Madjid Society, 2019.

Osman Raliby. Kamus Internasional. Jakarta: Bulan Bintang, 2000.

Peter Salim. Adventage: Inggris-Indonesia Dictionory. Jakarta: Moderen English Press, 1988.

Qomar, Mujamil. Manajemen Pendidikan Islam: Strategi Baru Pengelolaan Lembaga Pendidikan Islam. Erlangga, 2007.

—. Pesantren: Dari Transformasi Metodologi Menuju Demokratisasi Institusi. Erlangga, 2002.

Saputro, Anip Dwi. "Pembelajaran Aktif Dalam Dunia Pesantren." In Seminar Nasional Pendidikan 2015, 70-79, 2019.

Setiawan, Ebta. "Kamus Besar Bahasa Indonesia Versi Online." Dalam Kbbi. Web. Id/Kadas-2, Diakses Tanggal 10 (2013).

Silberman, Mel. Active Learning: 101 Strategies To Teach Any Subject. ERIC, 1996.

Sudijono, Anas. Pengantar Evaluasi Pendidikan. PT RajaGrafindo, 1998. 
Syaiful, Sagala. Konsep Dan Makna Pembelajaran Untuk Membantu Memecahkan Problematika Belajar Dan Mengajar. Bandung: Alfabeta, 2013.

Syaodih Sukmadinata, Nana. Pengembangan Kurikulum Teori Dan Praktek. Bandung: Remaja Rosda Karya, 2009.

Tanner, Daniel, and Laurel N. Tanner. Curriculum Development: Theory into Practice. Prentice Hall, 1995.

Yusuf, Muhammad, and Ismail Suardi Wekke. "Active Learning on Teaching Arabic for Special Purpose in Indonesian Pesantren." Procedia-Social and Behavioral Sciences 191 (2015): 137-141.

Zaenul Fitri, Agus. Manajemen Kurikulum Pendidikan Islam, Dari NormativeFilosofis Ke Praktis. Bandung; Alfabeta, 2015.

Zuhdy, Halimy. "Lingkungan Bahasa Arab Dan Perannya Dalam Belajar Dan Pembelajaran Di Pondok Pesantren Al-Amien Prenduan Sumenep Madura." Uin Maulana Malik Ibrahim Malang, 2007. 